\title{
UJI EFEKTIVITAS EKSTRAK GEL LIDAH BUAYA (Aloe vera) TERHADAP BAKTERI Propionibacterium acnes
}

\author{
Siti Fatimah ${ }^{1 *}$, Yuliana Prasetyaningsih ${ }^{2}$, Hermina Yostika Baru ${ }^{3}$ \\ ${ }^{1,2,3}$ STIKes Guna Bangsa Yogyakarta, Yogyakarta, Indonesia \\ Email: siti.fatimah.gunabangsa@gmail.com, \\ * corresponding author
}

\begin{abstract}
Abstrak
Jerawat adalah suatu keadaan dimana pori-pori kulit tersumbat sehingga timbul bintik merah dan abses yang meradang pada kulit. Pengobatan jerawat dapat dilakukan dengan pemberian antibiotik, namun mempunyai resiko resistensi terhadap tubuh dan dapat mengiritasi kulit.Untuk mengatasi hal tersebut diperlukan pengobatan alternatif menggunakan ekstrak gel Lidah buaya (Aloe vera) yang mempunyai kandungan tanin, lignin, saponin dan.barboloin. Penelitian ini bertujuan untuk mengetahui efektivitas antibakteri ekstrak gel lidah buaya (Aloe vera) terhadap bakteri Propionibacterium acne. Jenis penelitian ini adalah penelitian eksperimental dengan metode difusi cara sumuran. Ekstrak gel lidah buaya diekstraksi dengan metode maserasi dengan menggunakan etanol 70\% sebagai pelarut. Ekstrak gel lidah buaya yang diperoleh kemudian diencerkan dengan menggunakan PEG 5\% pada konsentrasi 60\%, 70\%, 80\%, 90\% dan $100 \%$. Sampel bakteri Propionibacterium acnes diperoleh dari jerawat orang yang matang yang diidentifikasi di laboratorium. Kontrol positif menggunakan klindamisin dan kontrol negatif menggunakanPEG 5\%. Hasil penelitian menunjukkan bahwa ekstrak gel lidah buaya pada konsentrasi $60 \%, 70 \%, 80 \%, 90 \%$ dan $100 \%$ memiliki rata-rata diameter zona hambat terhadap Propionibacterium acnes sebesar $6,7 \mathrm{~mm} ; 8,3 \mathrm{~mm} ; 12,7 \mathrm{~mm} ; 14,7 \mathrm{~mm} ; 17,3 \mathrm{~mm}$. Kontrol positif (klindamisin) sebesar 20,7 mm dan kontrol negatif (PEG $5 \%$ ) tidak memiliki nilai untuk dapat menghambat pertumbuhan bakteri. Ekstrak gel lidah buaya pada konsentrasi 80\%, 90 dan 100\% efektif dalam menghambat pertumbuhan bakteri Propionibacterium acnes, sedangkan konsentrasi 60\% dan 70\% tidak efektif dalam menghambat pertumbuhan bakteri Propionibacterium acnes.
\end{abstract}

Kata kunci: Aloe vera, Propionibacterium acne, antibakteri, antibakteri

\begin{abstract}
Acne is a condition in which the pores of the skin become clogged, resulting in red spots and inflamed abscesses on the skin. Acne treatment can be done by giving antibiotics, but it has a risk of resistance to the body and can irritate the skin. To overcome this, alternative treatment is needed using Aloe Vera gel extract which contains tannins, lignin, saponins and barboloin. This study aims to determine the antibacterial effectiveness of aloe vera gel extract against Propionibacterium acnes bacteria. This type of research is an experimental research with a welldiffusion method. Aloe vera gel extract was extracted by maceration method using $70 \%$ ethanol as solvent. The aloe vera gel extract obtained was then diluted using 5\% PEG at concentrations of 60\%, 70\%, 80\%, 90\% and 100\%. Samples of the bacteria Propionibacterium acnes were obtained from mature acnes identified in the laboratory. Positive control using clindamycin and negative control using PEG 5\%. The results showed that aloe vera gel extract at concentrations of $60 \%$,
\end{abstract}


70\%, 80\%, 90\% and 100\% had an average diameter of inhibition zone against Propionibacterium acnes of $6.7 \mathrm{~mm} ; 8.3 \mathrm{~mm} ; 12.7 \mathrm{~mm} ; 14.7 \mathrm{~mm} ; 17.3 \mathrm{~mm}$. Positive control (clindamycin) $20.7 \mathrm{~mm}$ and negative control (PEG 5\%) had no value to inhibit bacterial growth. Aloe vera gel extract at concentrations of $80 \%, 90$ and 100\% were effective in inhibiting the growth of Propionibacterium acnes bacteria, while concentrations of $60 \%$ and $70 \%$ were not effective in inhibiting the growth of Propionibacterium acnes bacteria.

Keywords: Aloe vera, Propionibacterium acneAbstracts, antibacterial

\section{Pendahuluan}

Jerawat yang bahasa medisnya disebut acnes vulgaris adalah suatu keadaan dimana pori-pori kulit tersumbat sehingga timbul bintik merah dan abses yang meradang pada kulit. Apabila hal itu terjadi, maka akan bercampur dengan make-up, keringat, dan polusi dapat tumbuh menjadi komedo. Jika komedo terinfeksi oleh bakteri maka akan melekat pada kulit (Sampelan, dkk., 2017). Faktor utama yang terlibat dalam pembentukan jerawat adalah peningkatan produksi sebum, peluruhan keratinosit, pertumbuhan bakteri dan inflamasi. Mikroorganisme seperti Staphylococcus epidermidis dan Propionibacterium acnes ikut berperan dalam patogenesis penyakit ini dengan cara memproduksi metabolit yang dapat bereaksi dengan sebum sehingga meningkatkan proses inflamasi (Widiawati, 2014).

Pengobatan jerawat dapat dilakukan dengan pemberian antibiotik seperti eritromisin, klindamisin, dan tetrasiklin. Namun Obat-obat antibiotik tersebut mempunyai resiko resistensi terhadap tubuh dan dapat mengiritasi kulit (Humphrey, 2012).Oleh karena itu diperlukan alternatif lain dalam mengobati acne vulgaris dari bahan alami yang diharapkan dapat meminimalkan efek samping dari penggunaan obat antibiotik tersebut. Lidah buaya mengandung 12 jenis antrakuinon sebagai antibakteri dan antivirus. Selain antrakuinon, lidah buaya mengandung kuinon, saponin, aminoglukosida, lupeol, asam salisilat, tanin, nitrogen urea, asam sinamat, fenol, sulfur, flavonoid dan minyak atsiri yang berfungsi sebagai antimikroba (Sulistyani, dkk., 2016).

Hasil penelitian dari Kamal dan Saputri (2018) infusa daun lidah buaya konsentrasi $5 \%, 10 \%$ dan $15 \%$ memiliki zona hambat optimum terhadap Propionibacterium acnes yaitu pada konsentrasi $15 \%$ dengan rata-rata zona hambat $23,13 \mathrm{~mm}$. Hasil penelitian Yusmaini dan Bahar (2018), rata-rata zona hambat ekstrak lidah buaya konsentrasi 25\%, $50 \%$ dan 75\% terhadap Staphylococcus aureus masing-masing 6,9 mm, 7,3 mm dan 9,14 $\mathrm{mm}$ dan rata-rata zona hambat ekstrak lidah buaya konsentrasi $25 \%, 50 \%$ dan $75 \%$ terhadap Propionibacterium acnes, masing-masing 7,2 $\mathrm{mm}, 15,1 \mathrm{~mm}$ dan $15,8 \mathrm{~mm}$. Tujuan penelitian ini adalah untuk mengetahui efektivitas antibakteri ekstrak gel lidah buaya (Aloe vera) konsentrasi 60\%, 70\%, 80\%, 90 dan 100\% terhadap bakteri Propionibacterium acnes.

\section{Metode Penelitian}

Jenis penelitian yang digunakan adalah penelitian true eksperimental yaitu Posttest Only Control (Rancangan Postest dengan kelompok kontrol). Dengan desain ini peneliti mengukur pengaruh perlakuan (intervensi) pada kelompok eksperimen dengan 
cara membandingkan kelompok tersebut dengan kelompok kontrol (Notoadmojo, 2010). Alat yang digunakan adalah tabung reaksi steril, ose bulat, inkubator, cawan petri, pipet ukur steril, neraca atau timbangan, oven, gelas beker steril, autoclave, dan pipet tetes. Bahan Penelitian yang digunakan adalah ekstrak gel lidah buaya (Aloe vera), Suspensi bakteri Propionibacterium acnes, aqudes steril, Nutrient Agar (NA),media glukoa, Media Blood Agar Plate (BAP), antibiotik klindamisin, $\mathrm{NaCl}$ fisiologis 0,85\%, Polyetilene Glycol (PEG) 5\%, dan Standar Mc Farland I (setara dengan 106 CFU).

Prosedur Penelitian meliputi tahap persiapan dan uji aktivitas antibakteri. Persiapan bakteri Propionibacterium acnes yang didapatkan dari orang yang berjerawat yang kemudian dilakukan pewarnaan gram sehingga didapatkan bakteri yang berbentuk gada dan berwarna ungu, koloni bakteri tersebut sudah benar-benar murni Propionibacterium acnes. Pembuatan ekstrak gel lidah buaya dengan metode ekstraksi yang dipakai dalam penelitian ini adalah metode maserasi. Lidah buaya dikupas kulitnya dan diambil gelnya kemudian ditimbang sebanyak 400 gram dan ditambahkan $1500 \mathrm{ml}$ etanol 70\%. Diaduk selama 30 menit, didiamkan 24 jam, kemudian disaring (diulang 2 kali). Setelah itu filtrat diuapkan dengan Vacum Rotary Evaporator pemanas waterbath suhu $60^{\circ} \mathrm{C}$ sehingga diperoleh esktrak daun lidah buaya yang kental. Pembuatan konsentrasi ekstrak gel lidah buaya dengan cara diencerkan dengan PEG (Polyetilene Glycol ) 5\% menjadi konsentrasi $60 \%, 70 \%, 80 \%, 90 \%$, dan $100 \%$. Langkah selanjutnya adalah pembuatan media blood agar plate dengan cara bubuk media blood agar base ditimbang sebanyak 40 gram kemudian dimasukkan ke dalam botol kaca. Dilarutkan dengan $1000 \mathrm{ml}$ aquades $\mathrm{pH} \pm 7$ (netral) kemudian dihomogenkan menggunakan stirrer magnetic. Botol kaca yang berisi media ditutup dengan tutup botol yang dilapisi aluminum foil dan diikat dengan benang. Media disterilisasi dengan autoklaf pada suhu $121^{\circ} \mathrm{C}$ selama 15 menit.Media yang telah steril didinginkan hingga mencapai suhu $45-50^{\circ} \mathrm{C}$. Ditambahkan 5-7\% darah kambing. Media dituang ke dalam plate dan ditunggu hingga padat.Setelah beku media siap digunakan.

Setelah langkah persiapan selesai dilanjutkan uji efektivitas antibakteri. Uji efektivitas ekstrak gel lidah buaya (Aloe vera) dilakukan dengan metode difusi, kemudian masing-masing konsentrasi ekstrak dimasukkan ke dalam sumuran yang telah dibuat pada permukaan media agar darah. Media diinkubasi selama 24 jam dalam inkubator dengan suhu $37^{\circ} \mathrm{C}$, setelah itu diameter daerah yang bening diukur menggunakan penggaris untuk mengetahui lebar zona hambat. Kontrol negatif (sumuran diberi PEG 5\%) dan untuk kontrol positif (sumuran diberi antibiotik klindamisin). Pengujian di lakukan dengan cara kapas lidi steril dicelupkan ke dalam suspensi bakteri Propionibcterium acnes kemudian ditekan-tekan pada dinding tabung sehingga tidak terlalu basah, kemudian dioleskan pada media Blood Agar Plate hingga rata. Sumuran yang telah dibuat dimasukkan masing-masing konsentrasi ekstrak gel lidah buaya hingga sumuran tersebut penuh.Pada cawan petri tepat di belakang sumuran, masing-masing dilabeli dengan konsentrasi $60 \%$, $70 \%, 80 \%, 90 \%$ dan $100 \%$.Diinkubasi pada suhu $37^{\circ} \mathrm{C}$ selama 24 jam.Pembacaan hasil diperoleh dengan mengukur diameter zona hambat di sekitar sumuran menggunakan penggaris berskala $\mathrm{mm}$. Tingkat efektivitas antibakteri ekstrak gel lidah buaya dengan variasi konsentrasi $60 \%, 70 \%, 80 \%, 90 \%$ dan $100 \%$ dapat ditentukan dengan mengukur presentase (\%) daya hambat menggunakan persamaan Oroh, dkk., (2015) :

$$
\mathrm{E}=(\mathrm{D} / \mathrm{Da}) \times 100 \%
$$


Dimana E: Efektivitas antibakteri (\%), D: Diameter zona hambat ekstrak gel lidah buaya (mm). Da: Diameter zona hambat antibiotika (mm). Menurut Oroh, dkk., (2015)., efektivitas antibakteri dikelompokkan ke dalam 2 kelompok, yakni tidak efektif dan efektif, dapat dilihat pada tabel 1.

Tabel 1. Pengelompokan efektivitas antibakteri menurut Oroh, dkk (2015).

\begin{tabular}{lcc}
\hline No & Persentase & Efektivitas \\
\hline 1 & $<50 \%$ & Tidak efektif \\
\hline 2 & $\geq 50 \%$ & Efektif \\
\hline
\end{tabular}

\section{Hasil dan Pembahasan}

Sebelum dilakukan penelitian dilakukan persiapan bakteri Propionibacterium acnes Bakteri ini diambil dengan cara jerawat dipencet dan diambil nanahnya menggunakan kapas steril, kemudian dimasukkan ke dalam tabung yang berisi media glukosa yang berfungsi untuk menumbuhkan bakteri lalu diinkubasi di dalam inkubator selama 1x24 jam dengan suhu $37^{\circ} \mathrm{C}$. Kemudian dilihat jika berubah warna merah menjadi warna kuning bakteri tumbuh yang artinya bakteri memfermentasi gula dan mengubah basa ke asam. Bakteri yang tumbuh di dalam tabung yang berisi media glukosa ditanam di media BAP (Blood Agar Plate) karena media ini merupakan media diferensial sehingga suatu mikroorganisme membentuk pertumbuhan untuk mengklasifikasikan suatu kelompok jenis bakteri. Media diinkubasi di dalam inkubator selama 1 x24 jam dengan suhu $37^{\circ} \mathrm{C}$, kemudian koloni bakteri yang tumbuh pada media BAP diindentifikasi dengan menggunakan pewarnaan gram untuk mengamati dengan lebih baik tampak morfologi bakteri dan untuk mengidentifikasi atau untuk menentukan jenis bakteri. Pada pewarnaan gram didapatkan bakteri yang berbentuk gada dan berwarna ungu merah, kemudian koloni tersebut dimurnikan dengan cara ditanam pada media NA diinkubasi di dalam inkubator selama $1 \times 24$ jam dengan suhu $37^{\circ} \mathrm{C}$, kemudian diidentifikasi lagi dengan menggunakan pewarnaan gram untuk mengetahui apakah sudah benar-benar murn. Pada pewarnaan gram didapatkan bakteri yang berbentuk gada dan berwarna ungu merah, koloni tersebut menunjukkan benar-benar bakteri Propionibacterium acnes seperti pada gambar 1.

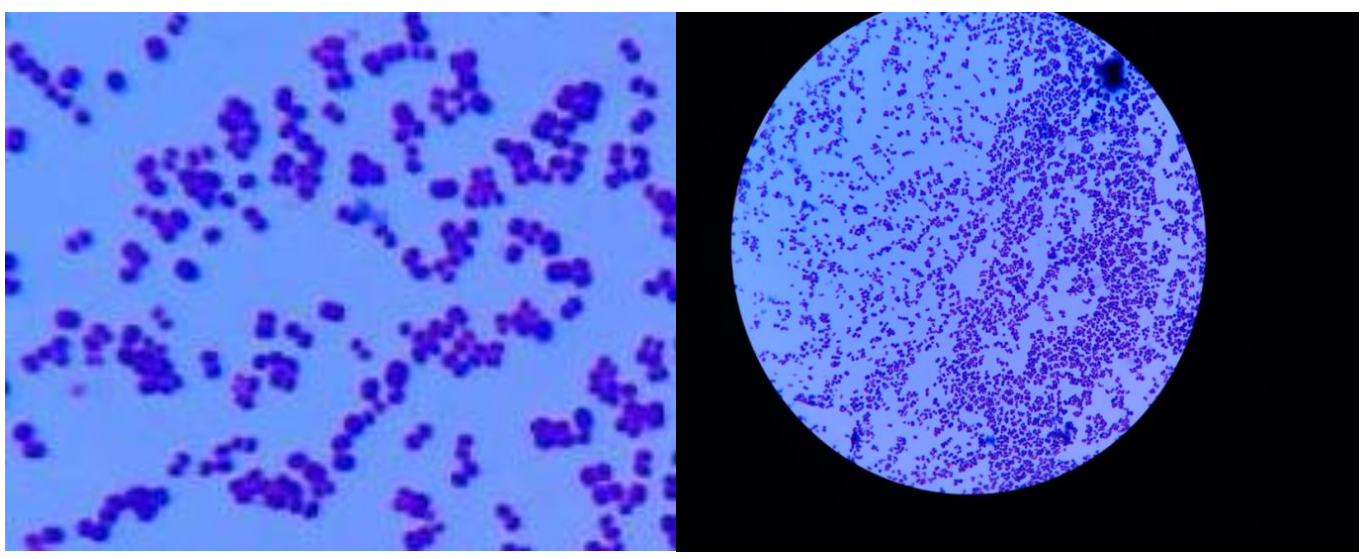

Gambar 1. Bentuk Bakteri Propionibacterium acnes Yang Diamati Dibawah Mikroskop Dengan Pembesaran Kuat 100x Menggunakan Minyak Imersi. 
Ekstraksi gel lidah buaya dilakukan untuk menarik zat aktif antibakteri flavonoid, saponin dan tanin yang menggunakan metode maserasi dengan pelarut etanol $70 \%$, sehingga menghasilkan ekstrak etanol $100 \%$ yang kemudian dibuat menjadi berbagai konsentrasi yaitu $100 \%, 90 \%, 80 \%, 70 \%$, dan $60 \%$. Kemudian dilakukan uji daya hambat menggunakan metode sumuran.Metode sumuran memiliki kelebihan dan kekurangan. Kelebihan dari metode sumuran yaitu lebih mudah mengukur luas zona hambat yang terbentuk karena bakteri beraktivitas tidak hanya dipermukaan atas media Blood Agar Plate saja tetapi sampai ke bawah sedangkan kekurangannya yaitu jika sumuran yang dilakukan tidak sama besarnya maka akan mempengaruhi hasil yang tidak stabil dan metode ini tidak dapat menentukan apakah suatu zat yang terkandung di dalam ekstrak bersifat bakterisida dan bakteriostatik. Adanya zona bening di sekitar sumuran menunjukkan aktivitas antibakteri. Diameter zona bening di sekitar sumuran yang berisi ekstrak gel lidah buaya diukur dengan menggunakan penggaris dalam satuan millimeter yang diukur dari sisi lingkaran zona bening hingga sisi zona bening yang tidak ditumbuhi oleh bakteri Propionibacterium acnes. Hasil zona hambat ekstrak gel lidah buaya pada media Blood Agar Plate dengan variasi konsentrasi terhadap bakteri Propionibacterium acnes dapat dilihat pada gambar 2.
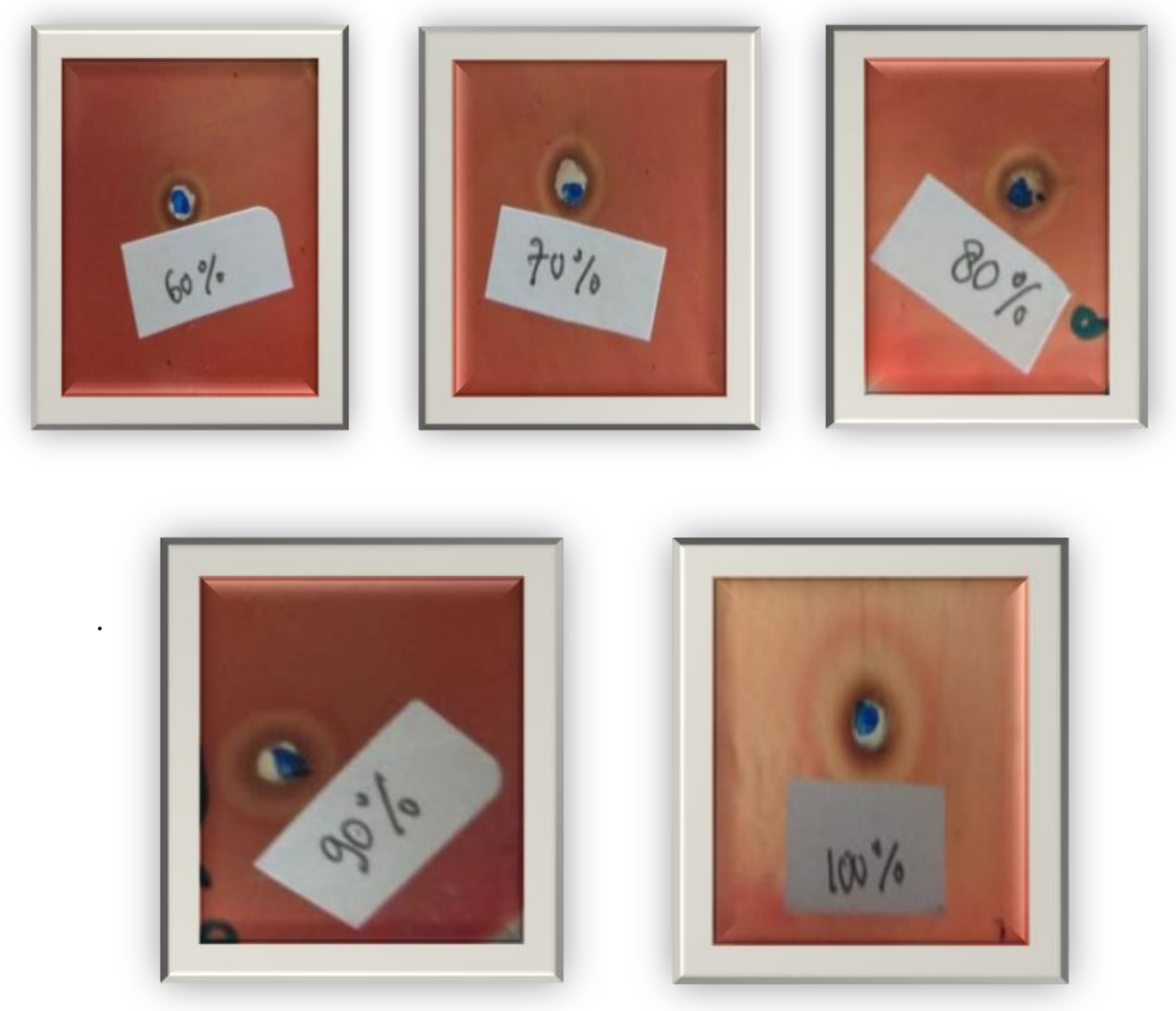

Gambar 2. Zona hambat Ekstrak Gel Lidah Buaya pada media Blood Agar Plate dengan Variasi Konsentrasi Terhadap Bakteri Propionibacterium acnes konsentrasi $60 \%, 70 \%, 80 \%, 90 \%$ dan $100 \%$ 
Berdasarkan hasil uji daya hambat pada gambar 2 di atas maka hasil uji efektivitas antibakteri gel lidah buaya dalam menghambat pertumbuhan Bakteri Propionibacterium acnes dapat dilihat pada tabel 3.

Tabel 3. Data Hasil Uji Efektivitas Ekstrak Gel Lidah Buaya (Aloe vera) Terhadap Bakteri Propionibacterium acnes.

\begin{tabular}{|c|c|c|c|c|c|c|c|c|}
\hline \multirow{2}{*}{ No } & \multirow{2}{*}{$\begin{array}{c}\text { Konsentrasi } \\
\text { Ekstrak Gel } \\
\text { Lidah } \\
\text { Buaya }\end{array}$} & \multicolumn{3}{|c|}{$\begin{array}{c}\text { Zona hambat } \\
(\mathbf{m m})\end{array}$} & \multirow{2}{*}{$\begin{array}{c}\text { Jumlah } \\
\text { (mm) }\end{array}$} & \multirow{2}{*}{$\begin{array}{c}\text { Rata- } \\
\text { rata } \\
(\mathbf{m m})\end{array}$} & \multirow{2}{*}{$\begin{array}{c}\text { Presentase } \\
\text { Efektivitas } \\
(\%)\end{array}$} & \multirow[t]{2}{*}{$\begin{array}{c}\text { Kategori } \\
\text { Efektivitas }\end{array}$} \\
\hline & & $\mathrm{A}$ & $\mathrm{B}$ & $\mathrm{C}$ & & & & \\
\hline 1 & $60 \%$ & 7 & 6 & 7 & 20 & 6,7 & 32,4 & $\begin{array}{l}\text { Kurang } \\
\text { efektif }\end{array}$ \\
\hline 2 & $70 \%$ & 9 & 8 & 8 & 25 & 8,3 & 40,10 & $\begin{array}{l}\text { Kurang } \\
\text { efektif }\end{array}$ \\
\hline 3 & $80 \%$ & 13 & 13 & 12 & 38 & 12,7 & 61,35 & efektif \\
\hline 4 & $90 \%$ & 15 & 15 & 14 & 44 & 14,7 & 71,01 & efektif \\
\hline 5 & $100 \%$ & 17 & 17 & 18 & 52 & 17,3 & 83,57 & efektif \\
\hline 6 & Klindamisin & 20 & 21 & 21 & 62 & 20,7 & & \\
\hline 7 & PEG 5\% & 0 & 0 & 0 & 0 & 0 & & \\
\hline
\end{tabular}

Hasil pengukuran zona bening pada pertumbuhan bakteri Propionibacterium acnes menggunakan ekstrak gel lidah buaya mendapatkan hasil uji efektivitas pada konsentrasi 80\% sampai $100 \%$ efektif dalam menghambat pertumbuhan bakteri Propionibacterium acnes. Berdasarkan hasil dari berbagai konsentrasi ekstrak gel lidah buaya yang diberikan ke dalam sumuran menunjukkan bahwa ekstrak gel lidah buaya tersebut mengandung suatu senyawa kimia yang berperan sebagai antibakteri terhadap bakteri Propionibacterium acnes. Hal tersebut ditunjukkan dengan terbentuknya diameter zona bening yang semakin besar dengan meningkatnya konsentrasi yang digunakan.

Berdasarkan hasil uji daya hambat didapatkan bahwa konsentrasi ekstrak gel lidah buaya (Aloe vera) dengan tiga kali pengulangan terhadap bakteri Propionibacterium acnes mampu menghambat pertumbuhan bakteri Propionibacterium acnes dimulai dari konsentrasi $60 \%$ hingga $100 \%$. Semakin tinggi konsentrasi ekstrak gel lidah buaya maka semakin besar diameter zona bening yang terbentuk. Uji daya hambat yang dilakukan tiga kali pengulangan mendapatkan hasil diameter zona hambat. Hasil uji daya hambat yang dilakukan tiga kali pengulangan dari konsentrasi $60 \%$ sampai $100 \%$ dihitung rata-rata diameter zona hambat yaitu dari konsentrasi $60 \%$ dengan rata-rata diameter $6,7 \mathrm{~mm}$, konsentrasi $70 \%$ dengan rata-rata diameter $8,3 \mathrm{~mm}$, konsentrasi $80 \%$ dengan rata-rata diameter $12,7 \mathrm{~mm}$, konsentrasi $90 \%$ dengan rata-rata diameter $14,7 \mathrm{~mm}$ dan konsentrasi $100 \%$ dengan rata-rata diameter $17,3 \mathrm{~mm}$. 
Hasil rata-rata diameter zona hambat ekstrak gel lidah buaya pada konsentrasi $80 \%$ sampai $100 \%$ memiliki antibakteri yang bisa dikelompokkan menurut Stout dalam Maryuni (2008), daya antibakteri di bagi menjadi 4 kelompok yaitu antibakteri dengan aktivitas rendah, sedang, kuat dan sangat kuat yang dapat dilihat pada tabel 4 .

Tabel 4. Pengelompokan aktivitas antibakteri menurut Stout (2008)

\begin{tabular}{ccc}
\hline No & Aktivitas & Diameter zona hambat (mm) \\
\hline 1 & Rendah & $<5$ \\
\hline 2 & Sedang & $5-10$ \\
\hline 3 & Kuat & $10-20$ \\
\hline 4 & Sangat kuat & $>20$ \\
\hline
\end{tabular}

Berdasarkan rata-rata zona hambat ekstrak gel lidah buaya pada konsentrasi $60 \%$ sampai $100 \%$ apabila dikaitkan dengan ketentuan seperti tabel 3 yang dikemukakan oleh Stout (2008), maka kekuatan antibakteri yang terkandung dalam ekstrak gel lidah buaya dengan konsentrasi $60 \%$ dan $70 \%$ masuk kategori sedang dan $80 \%$, 90\% sampai $100 \%$ masuk kategori kuat.Berdasarkan hasil rata-rata zona hambat pada konsentrasi $60 \%$ sampai $100 \%$ yang dikaitkan dengan tabel 4 yang dikemukakan oleh Stout (2008) maka dilanjutkan dengan uji efektivitas antibakteri dengan mengukur presentase (\%) daya hambat menggunakan persamaan Tangapo dalam Oroh, dkk., (2015) Hasil persentase efektivitas antibakteri ekstrak gel lidah buaya terhadap bakteri Propionibacterium acnes terlihat bahwa konsentrasi ekstrak gel lidah buaya dengan konsentrasi $60 \%$ dan $70 \%$ masuk dalam kategori kurang efektif dan pada konsentrasi $80 \%, 90 \%$ dan $100 \%$ masuk dalam kategori efektif.

Efektivitas yang masih rendah menandakan bahwa kadar senyawa aktif sebagai antibakteri pada ekstrak gel lidah buaya yang digunakan masih rendah. Pada konsentrasi ekstrak gel lidah buaya dengan konsentrasi $60 \%$ dan $70 \%$ didapatkan hasil kurang efektif sedangkan pada pengelompokkan aktivitas anti bakteri konsentrasi $60 \%$ dan $70 \%$ masuk kategori sedang dan konsentrasi $80,90 \%$ sampai $100 \%$ masuk kategori kuat dalam menghambat pertumbuhan bakteri Propionibacterium acnes dan efektif. Sedangkan klindamisin sebagai kontrol positif memiliki zona bening dan masuk kategori kuat dan efektif dalam menghambat pertumbuhan bakteri Propionibacterium acnes. Apabila dibandingkan dengan penelitian Yusmaini dan Bahar (2018), pada konsentrasi 75\% ekstrak gel lidah buaya dapat menghambat pertumbuhan bakteri Propionibacterium acnes tetapi belum efektif sedangkan pada penelitian Anita (2015) pada konsentrasi pencampuran gel 25\% daun biji : $75 \%$ lidah buaya sudah efektif menghambat pertumbuhan bakteri Propionibacterium acnes.

\section{Kesimpulan}

Ekstrak gel lidah buaya (Aloe vera) dengan konsentrasi 80\%, 90\% dan $100 \%$ efektif dalam menghambat pertumbuhan bakteri Propionibacterium acnes sedangkan Ekstrak gel lidah buaya (Aloe vera) dengan konsentrasi $60 \%$ dan $70 \%$ tidak efektif dalam menghambat pertumbuhan bakteri Propionibacterium acne. 


\section{Referensi}

Anita, S. (2015). Efektivitas Gel Campuran Daun Jambu Biji (Psidium guajava) Dan Lidah Buaya (Aloe vera) Untuk Mengurangi Radang Jerawat Pada Kulit Wajah. Skripsi. Fakultas Teknik Universitas Negeri Semarang

Humphrey S. (2012). Antibiotic Resistance in Acne Treatment. US National Library of Medicine and Pubmed, 17(9), 4-10.

Kamal, E.S., Saputri, D.S. (2018).Uji Aktivitas Infusa Daun Lidah Buaya (Aloe Veral.) Terhadap Propionibacterium acnes Penyebab Jerawat. Jurnal Farmasi Sandi Karsa, $4(7)$

Notoadmojo. (2010). Metodologi Penelitian Kesehatan. Jakarta : Rineka Cipta: 37-38

Oroh, S. B. Kandou, F. E. F. Pelealu, J. Pandiangan, D. (2015). Uji Daya Hambat Ekstrak Metanol Selaginella delicatula dan Diplazium dilatatum Terhadap Bakteri Staphylococcus aureus dan Escherichia coli. Jurnal Ilmiah Sains, 15 (1), 54

Sampelan, M. G. Pangemanan, D. dan Kundre, R. M.( 2017). Hubungan Timbulnya Acne vulgaris Dengan Tingkat Kecemasan Pada Remaja Di SMP N 1 Likupang Timur. e-Journal Keperawatan (e-Kp), 5(1), 2.

Stout dalam Maryuni. (2008). Aktivasi Antibakteri Tanaman Bandotan (Agerantum conyzoiaes Linn). Terhadap Bakteri Escherichia coli dan Staphylococcus aureus. Karya Tulis Ilmiah. IPB. Bandung

Sulistyani, N. Kurniati, E. Yakup, dan Cempaka, R. A. (2016). Aktivitas Antibakteri Infusa Daun Lidah Buaya (Aloe barbadensis miller). Jurnal Penelitian Saintek, $21(2,121$.

Widiawati, W. (2014). Perbedaan Hasil Penyembuhan Kulit Wajah Berjerawat Antara Masker Lidah Buaya Dengan Masker Non Lidah Buaya. e- Journal Tata Rias, 3(1), 218.

Yusmaini, H. dan Bahar, M. 2018. Efek Antimikroba Ekstrak Lidah Buaya (Aloe vera) Terhadap Isolat Bakteri Penyebab Acne Vulgaris Secara In Vitro. Jurnal Profesi Medika, 11(2), 3 . 